\title{
PARTY ALLIANCES AND POLITICAL COALITIONS DURING THE 2007 GENERAL ELECTION IN LESOTHO
}

\author{
Francis K Makoa
}

Professor Francis Kopano Makoa is a senior lecturer in the Department of Political Studies at the National University of Lesotho, where he is also Dean of the Faculty of Social Sciences

Tel: +266 22213659

Fax: +266 22340000

e-mail: fk.makoa@nul.ls

\begin{abstract}
In 2007, for the first time in Lesotho's political history, some political parties formed formal electoral pacts, variously dubbed alliances or coalitions ${ }^{*}$, to fight the general election of 17 February. The ruling Lesotho Congress for Democracy and the newly formed All Basotho Convention entered into alliances with their smaller counterparts, the National Independent Party and the Lesotho Workers' Party respectively, as polling day neared. While the benefits of these alliances for the partners may not be in doubt, what is doubtful is the ability of the arrangement to expand democracy and comply with the goal and thrust of the mixed member proportional electoral and parliamentary model adopted as a panacea for incessant election-centred conflict. Also raising serious questions is the apparent fraud that went along with the process of forming the alliances. Yet this conundrum inheres in the country's two-ballot electoral system, which apparently allows political parties registering for elections to choose between fielding candidates in constituencies and targeting party votes only.
\end{abstract}

\section{INTRODUCTION}

The split in August 2006 in the ruling Lesotho Congress for Democracy (LCD) and the formation by those who left it of the All Basotho Convention (ABC) brought about a change in Lesotho's erstwhile bipolar political map, which, until * For the purposes of simplicity the word alliance will be used throughout this paper except where the
distinction between alliances and coalitions is necessary 
that time, had featured fierce contests between two big rival political parties, each with a history dating as far back as the 1950s, when growing nationalism crystallised into the independence movement.

These two parties were the Basotho National Party (BNP), which led Lesotho to independence in 1966, and the LCD, a faction of the Basutoland Congress Party (BCP), which had governed the country since June 1997. A major concomitant of the LCD split and the subsequent emergence of the $A B C$ was a shift in the alignment of political forces.

The ABC has replaced the BNP as the LCD's bitter and formidable foe, consolidating its position as the country's second-largest political party and a serious challenger to the LCD through an electoral alliance with one of the smallest but most strategically placed parties. Thus, the ABC heads an alliance which has a total of 27 seats in Parliament. Meanwhile, with its slender constituency-derived parliamentary majority of just two, giving it a precarious hold on governmental power, the governing LDC has been forced to maintain, albeit without openly acknowledging it, its alliance with another of Lesotho's miniscule political parties as a quid pro quo for the latter's support.

Both parties took advantage of the dual constituency and party-vote electoral system to increase their chances of victory in the 2007 election. The ABC was joined by the Lesotho Workers' Party (LWP), the LCD by the National Independent Party (NIP), amid protests which culminated in an unsuccessful legal action by the NIP's leader.

Lesotho's electoral system entails a dual vote involving two ballot papers, one for a constituency candidate, the other for a party. Party votes are particularly important to and of immense value for small parties whose chances of winning a constituency and thus a parliamentary seat are slim, if not non-existent.

With party votes only, each party contesting an election has a fair chance of capturing a proportional representation (PR) seat in the National Assembly. Thus small parties join in alliances with larger ones in order to increase their chances of winning seats. But the lesson offered by the February 2007 election is that, in practice, this has meant exchanging their right to contest constituency seats for party PR votes determined according to the terms of the alliance agreements.

While the legality or otherwise of such an exchange remains unclear and perhaps a matter for debate, the LWP and the NIP contracted not to field candidates in constituencies, an agreement that was permitted by the Independent Electoral Commission (IEC). Instead, they and their senior partners provided a joint list of PR candidates to the IEC, expecting party votes mainly from LCD and $\mathrm{ABC}$ members according to the alliance agreement. During this period another alliance emerged which differed from the other two because it registered as a party. It was formed by splinter groups of the $\mathrm{BCP}$, namely the Basutoland African 
Congress (BAC), the Lesotho Peoples' Congress (LPC) and Mahatammoho-aPoelano, and, calling itself the Alliance of All Congress Parties (ACP), contested the February election as a single party.

These alliances have plunged into a crisis, if not entirely discredited the MMP model, which had, since 2002, been touted as a panacea for Lesotho's hitherto recurrent political conflict, which was assumed to have been linked to 'the inequities of [the] simple majority vote or first-past-the-post (FPTP)'-based electoral system used in the country (Makoa 2000, p 233). But the formation of alliances has exposed the fallacy underlying the assumption of advocates of the MMP that a change of system 'would automatically lead to changes in the existing political attitudes and values in Lesotho' (Makoa 2005, p 180) reproduced through and sustained by fierce power struggles involving a politics of exclusion and denial by large parties of political space for their smaller and less competitive counterparts. Their size in terms of votes polled enabled the LCD / NIP and ABC / LWP alliances to squeeze the other parties out of the competition for state power, reducing them to insignificance. The positive side of the February 2007 election alliances, though, is that they unmasked the MMP's inherent conundrum, which had been hidden until a dispute arose over the allocation of PR seats.

The question is whether Lesotho's MMP system permits individual political parties to register for and contest elections without fielding candidates in constituencies and, if so, what implications this has for individuals seeking election. In fact, the conundrum is broader, extending to the issue of how a government formed by a winning alliance or coalition should be classified.

Acknowledging the fact that the alliances which emerged as Lesotho prepared for the February election are, in principle, critical props of democracy and legitimate ways of participating in the process of appointing rulers and fighting political battles, this paper comments briefly on these phenomena, noting their link with the country's dual ballot system and its inbuilt problems, and suggesting ways of resolving these problems.

\section{ALLIANCES AND COALITIONS}

The conceptual delineation between alliances and coalitions, if any, is thin, and sometimes blurred, so the difference between them is circumstantial and contextual. Indeed, as concrete phenomena the two represent and signify solidarity groups, of which national states are some, working together and cooperating in an endeavour to achieve a specific goal. Thus, as descriptive terms the two have rightly been used interchangeably and synonymously.

These observations notwithstanding, an alliance and / or coalition is a formal cooperation based on an agreement between or among two or more organised 
groups about specified activities. The concepts connote and describe a collective and co-operative approach by two or more distinct formal organisations (including states), with similar objectives and outlooks, however temporary and time-bound, the challenge or predicament facing them.

Two levels of abstraction and/or conceptualisation apply to the study and analysis of alliances and/or coalitions. These are the global/inter-state or international politics and the domestic/intra-state setting. The former applies specifically to analyses of inter-state interactions and relations involving formal cooperation and/or collaboration and uses as schema in viewing and conceptualising such interactions and relations theories of foreign policy and international relations, most of which are rooted in realist political thought.

Holsti \& Berridge's definitions are instructive. For Holsti (1983, pp 106-7) alliances or coalitions are strategies and commitments used to maintain solidarity. States come together, while retaining their sovereignty, in a special partnership with agreed conditions to be observed by each of the partners for the purpose 'of obtaining more favorable ... relations', and require varying types and degrees of commitment on the part of the alliance or coalition partners. Similarly, Berridge (1992, p 176) views an alliance as a 'contractual commitment entered into by two or more states engaged in cooperative ... action in specified circumstances'. Berridge (1992, p 178) notes that states often enter into loose, or what he terms 'entente'-type alliances or coalitions whereby 'commitments are implicit rather than explicit ...'.

At the domestic or intra-state level of abstraction an alliance or coalition is and must be conceptualised as collaboration and cooperation in pursuit of common goals between and among national organisations. The most common occur between political parties, liberation movements, and trades unions and invariably assume the character of a contract defining the rights of the cooperating parties.

As is the case with states, political party alliances or coalitions are formed to address specific issues. Familiar and recurrent issues are elections, referenda, crucial legislation, members' motions, and the formation of governments where there is either no outright winner or where the best-performing party has a slender majority. Indeed, this is the core of alliance or coalition theory and is cited and employed as a measure by virtually all analysts of coalitions.

One writer has cast this theory as a scheme subdivided into two distinguishable clusters with different philosophical strands and orientations, namely, office-driven and policy-oriented theories. Also dubbed office seeking or office oriented, the first cluster assumes that 'the main goal of political parties is to access power' (Kadima 2006, p 5).

Recent work on political party alliances or coalitions in Africa includes that of Volden \& Carruba (2004) Oyugi (2006) and Kadima (2006). Volden \& Carruba 
(2004, p 521) comment on Ryker's much-debated notion of minimum winning coalitions, which they sum up as: 'if governments are office-seeking - meaning parties join governments in order to divide up the benefits of controlling the executive - governments should include just enough parties to assure majority support in the electing house ... Oversized coalitions would simply divide the perks of office among more actors than necessary.' They maintain that 'while ... descriptively accurate, it does not appear to explain why' the phenomenon of oversized coalitions is perpetuated. In sum, Ryker's contention has not, in all cases, tallied with what has been observed, nonetheless, it remains a useful tool for looking at political party alliances.

Oyugi (2006, p 53) observes that a '[c]oalition or alliance, involving formation both before and after elections is more often than not designed to serve the individual and collective interests of the cooperating parties'. But he seems to suggest that there are no fixed rules or precepts governing decision-making relating to coalition or alliance formation. Thus he asserts further that 'sometimes these alliances are opportunistic in character. At other times they are guided by principles based on the established values and ideologies which the partner parties avow.' However, these are not and cannot always be sufficient to be guides to decision-making in this regard. Arguably, normative frameworks for elections, such as national constitutions and electoral laws, would inform decisions about whether to form an alliance or coalition and even become an overriding factor in such decisions, determining the form, nature, and scope of the role of party coalitions, and the claims they may or not make on the political system.

Other writers see a political party alliance or coalition as more than simply two or more political parties agreeing to cooperate and actually cooperating to increase their chances of winning elections. Karume (cited in Oyugi 2006, p 54), for example, contends that ' [c]oalition building is a process of organizing parties collectively in pursuit of a common goal'. He premises his view on the fact that there is a range of activities involved in forming coalitions. Units forming the coalition have to agree on matters such as the distribution and sharing of expected benefits, responsibilities and roles - in other words, coalitions are a means to an end and have no intrinsic value.

The fact that party coalition theory does not, as Oyugi points out, show 'how coalitions are formed before and after elections' suggests that its predictive power is low, or even doubtful. In fact, processes of coalition formation may not always be free from cheating, chicanery, corruption, fraud, and manipulation. After all, political party leaders do not always reveal all the implications of their party coalitions and, in some cases, larger, richer parties may easily secure a coalition arrangement with their smaller poor counterparts through a bribe or other devious means. But if achieved thus the coalitions are likely to suffer 
legitimacy or credibility problem. The observations above notwithstanding, the theory, as sketched in this section, provides a useful lens through which to examine the present party coalitions in Lesotho.

\section{WHENCE POLITICAL PARTY ALLIANCES?}

The phenomenon of party alliances is integral to and a dynamic of the process of political development. However, in many polities today they have been, perhaps correctly, associated with and believed to be encouraged and nourished by multipartyism. Multipartyism is a system which includes more than one political party, with additional parties capable of cooperating and able freely to choose to cooperate in different ways, which include alliance or coalition formation. But multipartyism reflects and denotes a particular form and degree of political development or transformation.

This said, though, the argument for multipartyism is that multiparty systems not only provide for the formation of political parties but allow them to compete for state power through freely contested elections. Such competitive elections, however, often do not produce clear-cut winners with sufficient majority support to form an effective government. The defining features of an effective government are an unimpeded ability to enact and enforce laws or change them and to adopt the policies of its choice without fear that the opposition may oppose or overturn them whenever it chooses.

Multiparty democracies offer both freedom and scope for different parties to cooperate either permanently or temporarily in order to fight elections, or to form a government in the event that elections fail to produce an outright winner able to govern alone. This has been a feature of the majority of Western liberal democratic states. As Levine (1993, p 177) observes, 'every Western European state has been governed by a coalition for at least some time in the twentieth century.'

However, multipartyism in itself is not a predictable variable and does not explain the reasons underlying the formation of political party alliances or coalitions. Nor does it, on its own, spur political parties to cooperate and contest elections jointly. Rather, as a system of myriad political parties, it eases the formation of and offers expanded scope for and freedom to form party alliances or coalitions.

As the theory highlighted above shows political parties take the decision to join in alliances or coalitions after assessing the benefits of such alliances. Admittedly, social organisations, including political parties, are subject to influence by their environment and this determines and shapes their nature and structure by providing the normative/ legal setting that defines their degree of freedom. 
The formation of national election alliances or coalitions is the monopoly of political parties because of their distinctive character and objectives and the purpose that marks them off from other organisations. As Haque, Harrop \& Breslin (1993, p 234) argue, a political party is distinguishable from other societal organisations by the fact that it seeks to occupy a position of authority within the state, which, in a multiparty system, it does by contesting elections. Its chief defining feature is ' [a] conscious aim (realistic or not) to capture decision-making power, alone or in coalition'. 'A political party seeks political power either singly or in co-operation with other political parties ... to prevail over the others in order to get power or to stay in it' (Ball 1993, p 79). This is the main motivation for parties forming alliances. 'Losing parties that aren't far apart ideologically quickly recognize their advantage is to combine forces for the next elections. Then this new party wins, forcing other small parties to combine' (Roskin, Cord, Medeiros \& Jones 2000, p 239). To this extent, political party coalitions anticipate and respond to known vicissitudes of the democratic process, namely, competition and the ever-looming possibility of loss of power by the governing party or coalition of parties. There is little or no doubt that the coalescing Lesotho political parties anticipated and responded to the looming possibility of a loss or an inadequate parliamentary majority after the elections.

Alliances or coalitions have been formed both before and after elections and have even survived them and continued after elections have been won or lost. Those formed before elections are initially intended to maximise the chances of an electoral victory for the alliance partners. Those forged after elections have served as devices for forming a government where a majority party or coalition is unable to do so. At times the inability of a government to implement policies, pass laws, or push its programmes through Parliament prompt it to seek a coalition with one or more opposition parties. But post-elections alliances or coalitions formed by opposition parties would also aim to beef up their strength in order to become a countervailing force to the ruling party or governing coalition of parties, thus ensuring accountability by the latter. Sometimes alliances or coalitions are formed in order to secure a desired status, such as recognition as the official opposition.

In parliamentary democracies leaders of the official opposition have special entitlements and privileges. Lesotho's current system of government provides for an official opposition which is the second-largest party or coalition of parties in Parliament. The leader of the opposition in the case of Lesotho is, according to s 3 of the Members of Parliament Salaries Act 1998, 'a member of the National Assembly who is the leader of the political party or coalition of political parties who commands the majority in the opposition and his party or coalition has at least $25 \%$ of the total membership of the National Assembly' (cited by Hon 
N Motsamai 2007, p 20). However, to the chagrin of the ABC-led alliance which had written a letter to the Speaker claiming the status of official opposition, the Speaker cited this section as the reason for dismissing the claim as baseless.

\section{EXAMPLES IN EASTERN AND SOUTHERN AFRICA}

As stated above, multiparty democracies have made the formation of both political parties and political party alliances or coalitions both possible and easy. Admittedly, though, dictatorships, in whatever form, have also stimulated, albeit not as a deliberate project, the growth of resistance groups and liberation movements which have coalesced into alliances, cooperating in various ways to challenge these regimes.

Examples include those that emerged in the erstwhile white-minority ruled states in Southern Africa, namely Angola, Mozambique, Namibia, South Africa (where an alliance of congresses was formed to formulate a response to institutionalised racism), and Zimbabwe. In all these countries the oppressed native people formed, in the guise of resistance and liberation movements, broadly-based coalition forces which collaborated and cooperated, as their situations impelled them, in fighting their oppressors.

The drive to democratisation in Africa which began towards the end of the 1980s saw a proliferation of political parties, some of them too small and weak to compete effectively in national elections. Examples include that of Kenya, which had 15 parties in 2002 when the Moi regime agreed, in the fact of internal and international pressure, to embrace democracy fully. Since these parties could not, as independent and isolated units, dislodge the Moi government from power, they formed the National Rainbow Coalition (NARC), which, after its victory in the December 2002 election, replaced the Kenya African National Union (KANU) as Kenya's ruling party (Kadima \& Owuor 2006, pp 179-80).

There were similar developments in Malawi where the country's shift to multipartyism at the beginning of the 1990s resulted in the mushrooming of no fewer than 30 parties by 2004. These later collapsed themselves into alliances or coalitions in order to enhance their ability to compete in elections, beginning with those held in 1995 (Kadima \& Lembani 2006 p 123).

Mauritius has had party coalitions since the colonial era and all general elections bar one 'have been fought between two coalitions' (Kadima \& Kasenally 2006, p 73). As indicated above, South Africa has had a system of party alliances or coalitions since before the achievement of majority rule.

Alliances among white Afrikaner-dominated cultural groups and political parties were already being formed in South Africa in the 1920s, mainly as the Afrikaners began to challenge British influence over the country's administration 
and economy. Among blacks alliances were formed by resistance and solidarity groups reacting to racial oppression. Such solidarity groups are also the forerunners of modern black political parties.

The South African Native National Congress (SANNC) - later to become the African National Congress (ANC) - was founded in 1912 in Bloemfontein, South Africa, to increase the rights of black South Africans. In the 1950s the ANC formed an alliance (which would become known as the Congress Alliance) with the South African Indian Congress, the Coloured People's Congress, and the Congress of Democrats to broaden the basis of its opposition to the apartheid government.

In April 1994, in a tripartite alliance with the South African Communist Party and the Congress of South African Trade Unions, which exists to this day, the ANC won a landslide victory in the 1994 general election, But there was also a formal, if temporary alliance between the ANC and the mainly Zulu-based Inkatha Freedom Party (IFP), forged immediately after the 1994 elections mainly as a strategy to put an end to the 'black-on-black' violence that had been stoked by apartheid forces.

After its break with the IFP the ANC entered into an alliance with a faction of the (now defunct) New National Party (NNP) in an attempt to mollify hard-line conservative Afrikaners who were not yet ready to embrace post-apartheid majority rule. The alliance succeeded in isolating extremist Afrikaners, who still harboured the dream of an independent state. In addition there have been shifting and unstable alliances among opposition parties in South Africa with no real significance in as far as the attainment of state power is concerned.

Since 1994 South Africa has witnessed an atrophying and weakening opposition and the growth of ruling party hegemony. The ANC is still the dominant party, offering little political space for the opposition, even though, at local government level, some councils are controlled by its rivals. The politics of party alliances plays itself out at this level, particularly in Cape Town and the rural areas of KwaZulu-Natal.

South Africa's main opposition party, the Democratic Alliance (DA), initially brought together under a single banner and leadership small white liberal political parties in order to ensure a role for them in governance. The DA has cooperated and / or collaborated during elections with a variety of parties, including the IFP in KwaZulu-Natal. Despite this, it has failed to grow into a major force.

\section{PARTY ALLIANCES FORMED TO CONTEST THE 2007 GENERAL ELECTION}

Like the countries noted above Lesotho has experienced both pre- and post-election social movements and party alliances which were integral to and catalysts and 
consequences of the political transformation in the country. As the struggle for independence gathered pace towards the end of the colonial period the country's three influential modern political parties, the BCP, the Marematlou Freedom Party (MFP) and the BNP, were firmly established as contenders for power and poised to compete for control of the post-colonial state.

Until 1965 Lesotho had seen a slightly different type of political party alliance, gentlemen's-agreement-based, with no formal contracts but united by what they perceived as the common enemy, namely the oppressive alien rule. The first of these alliances, forged in the 1950s, was the $\mathrm{BCP} /$ trade union solidarity and cooperation during the struggle against colonialism. In its formative stage the $\mathrm{BCP}$ was no more than a collection of diverse socio-political forces which included trades unions and small traders held together by nationalism and anti-colonialism.

The first trade union federation to be registered in the country, the Basutoland Federation of Labour (BFL), became an ally of the BCP. This opened the way for some of its leaders and members to be elected to the party's executive committee. The national cooperative movement was another important ally of the BCP and its captive constituency and recruiting ground (Strom 1978, p 69). Ntsu Mokhehle, then leader of the then Basutoland African Congress (BAC), later the Basutoland Congress Party, became president of the Basutoland National Teachers Association (BANTA), some of whose members had joined him in forming the BAC (Nyeko 2002, p 156). BANTA thus became not just another important ally of the BCP but its leadership supply source and training ground.

As was to be expected, however, this broad alliance gradually degenerated into a form of non-state corporatism so that, by the 1960s, both the BFL and the cooperative movements had become mere support organisations for and lackeys of the BCP. No further alliances were formed until 1965. However, the immediate aftermath of the independence-paving general election of that year witnessed a resurgence of these phenomena. They took the form of entente-type alliances spearheaded by the BCP and the MFP and uniting the defeated political parties, which sought only to unseat the BNP, which had gained a narrow electoral victory.

The alliance gave the two political parties the cloak of representivity in later appeals to the United Nations and to the then Organisation of African Unity (OAU) in New York and Addis Ababa, respectively, for the dissolution of the BNP administration. A temporary arrangement, however, the coalition dissipated a few months after Lesotho attained independence, with the BNP government using the police to squash the two parties' challenge to its rule.

However, the BCP, unable to field a candidate in the Thaba-Putsoa constituency during the abortive 1970 election, asked its supporters to vote for the MFP candidate there, who won. This brief history suggests that the vicissitudes of nationalist politics and the attendant struggles against colonial rule not only 
necessitated the formation of political movements or parties to confront colonialism but also reminded such movements or parties of the adage that 'unity is strength'.

The 1970 state of emergency and formal ban on party political activity obliterated the constitutional rule and multiparty democracy that had nourished or facilitated the formation of party coalitions. The phenomenon only resurfaced well after the country's return to constitutional rule based on multipartyism. More importantly, it was only after the 1993 election, with its familiar single-partyParliament result, that coalitions became an option in the struggle for political power.

Dissatisfied with this development losing parties and some elements of civil society worked together to agitate for change in the electoral system, ultimately pressurising the king to dissolve the BCP government in August 1994. The pressure group was led by the BNP, but it did not form a formal coalition. A more formidable alliance, albeit not contract-based, was formed after the 1998 election, when the $\mathrm{BCP}, \mathrm{MFP}$ and BNP joined up to oppose the results. Here again the purpose was to unseat the LCD government and replace it with what the parties termed a government of national unity, in which they would participate. But the most significant development in this regard came in 2006, occasioned by and largely a result of the split in the ruling LCD and its loss of 27 members of Parliament, who crossed to the newly-formed $\mathrm{ABC}$.

As noted in the introduction to this paper both the $L C D$ and the $A B C$ rushed to forge electoral alliances with minuscule political parties as the country prepared for the February 2007 election. The LCD's loss of a further 18 constituencies in the most recent election has apparently served as a warning to the ruling party that it must remain in and perpetuate the pre-election alliance it forged with the NIP, one of the smallest parties in the country, with no political significance outside the coalition, and even to form a coalition government, although it shies away from admitting this openly. For the LCD the coalition with the NIP has not just been a strategy for winning the election but a critical prop of the LCD government in that, in Parliament, NIP members vote with the ruling party, thus assuring it of a majority. Moreover, some ministers in the current LCD government won their parliamentary seats through their includison in the NIP's list of proportional representation nominees submitted to the IEC prior to the elections.

The conjurers of this coalition approach to the election were the two big parties, for only they had a realistic chance of winning a substantial number of constituencies and governmental power through party votes transferred to their junior partners. The contractual arrangements - approved, countenanced and / or tolerated by the IEC - were that the smaller partners should not field constituency candidates but merely provide PR lists as per the requirements of the dualballot system. 
However, these lists had to include, and, indeed, did include, as a majority, members of the bigger partner parties. Although each partner decided on its own candidates for the PR seats, subject to agreed proportions, the final joint PR list (consisting of the statutory 40 candidates) submitted to the IEC was presented as exclusively that of the smaller partner. In the case of the ABC/LWP alliance $\mathrm{ABC}$ members constituted roughly 80 per cent of the total number (Macaefa 2007). The overall number of PR seats formally won by the LWP is ten, but, sharing these in accordance with the above ratios, the party would be entitled to two, while its bigger partner, the $\mathrm{ABC}$, would get the remaining eight.

The LCD / NIP coalition agreement, by contrast, provided officially for equal numbers of PR candidates, that is, 50 per cent for each of the partners. After the elections the NIP was nominally allocated a total number of 21 PR seats, which it shared according to the coalition contract, receiving 10 seats to the LCD's 11 (Motikoe 2007), thus increasing the latter's parliamentary majority from 62 to 73. While the advantage to the NIP, which might have won only one seat if it had not entered into the partnership, is admittedly phenomenal, the real beneficiary is the LCD, whose government would probably have collapsed or remained under the threat of collapse without this coalition.

The coalition has survived the election and the two parties have maintained their cooperation and solidarity, working closely together as a united force in Parliament. Having officially declared before the election that they would not compete for PR seats, both the LCD and the ABC automatically forfeited or renounced their otherwise legal right to claim such seats. Thus, in fact, without the NIP support the LCD would have won only 62 constituency seats, a number that dropped to 61 at the end of August 2007 after one LCD MP died. The LCD/ NIP and $\mathrm{ABC} / \mathrm{LWP}$ coalitions have had far-reaching consequences for the MMP model, adopted in 2002 to ensure representation in Parliament for smaller parties. Not only has it been used as a means of allocating PR seats to the LCD and the $\mathrm{ABC}$, which had not submitted lists in this respect to the IEC, it has also given Lesotho an undeclared or non-formalised coalition government tinged with fraud and controlled and dominated by the LCD, with little room for meaningful participation by its miniscule partner.

Thus, by virtue of its 50 per cent share in what are dubbed NIP PR parliamentary seats, which have allowed it to appoint no fewer than four Cabinet ministers, the present Lesotho government is in reality a LCD/NIP coalition government. The issue is not whether or not the LCD would have been able to form a government alone, what is important is that the four Cabinet ministers and the remaining seven so called NIP members are, in fact, LCD members. Arguably, the LCD would have had difficulty pushing through critical legislation or introducing and implementing some of its policies with only 63 MPs. In 
summary, the survival of the coalition has assured the LCD of the 'working' parliamentary majority it needs in order to govern the country.

The ABC/LWP alliance has been enlarged since the February 2007 election by the cooption of four more opposition parties - the BNP, the Alliance of Congress Parties (ACP), and the MFP - protesting at the way the PR seats were allocated. Another reason for expanding the alliance was to ensure that the $A B C$ gained at least one-quarter of the total number of parliamentarians in order to be recognised as the official opposition. This solidarity among independent units commits them to conducting their business as a unified parliamentary opposition under a single leader.

The parties that united to form the ACP, by contrast, gave up their individual names and/or identities, registering as the ACP and forming a single unified management structure or executive committee. According to a member of its management hierarchy the ACP was formed not merely to enhance the competitiveness of the constituent parties but as part of a process to unite into a single party once more all the $\mathrm{BCP}^{\prime}$ 's breakaway factions, including the ruling LCD (Raditapole 2007).

The ABC, ACP, BNP, LWP, and MFP seem bent on advancing their existing cooperation beyond, for example, solidarity involving voting together and recognising one leader. They declared their readiness and willingness to contest as a united force, fielding one alliance candidate in a by-election in the Mekading constituency in October 2007 (Nyaka 2007, p 9) although this plan did not materialise, for reasons that were never explained by the parties. The remainder of the small opposition parties - the BCP, the Popular Front for Democracy (PFD), the Basotho Democratic National Party (BDNP) and the Basotho-Batho Democratic Party (BBDP), each of which has one seat - have recently announced their desire to work together in some form of post-election coalition. This plan has, thus far, not been translated into reality.

The attitudes of party leaders and alliances and the realignment of forces as the country geared itself for the February 2007 general election are rooted in and underscore the conundrum inherent in the electoral system, that is, its dichotomous nature. Ironically, without this bifurcation there would be no MMP, for this is achieved only when voters vote both for a constituency candidate and a party of their choice. However, the consequences of this duality are profound. First, it simply reallocates to the big partner, via its small one, the votes cast for it. Second, it distorts the picture of voting patterns, thereby concealing information about the choices made by the voters. Third, it permits fraudulent electoral manoeuvres aimed at winning elections at all costs, even by undermining the spirit of the MPP model, as the ABC and the LCD have done. They have collected party votes through proxies, otherwise dubbed allies or 
coalition partners, who would probably not otherwise have won even a single PR seat.

There are lessons to be learned from the February 2007 election, the disputes that have greeted its outcome, the allocation of PR seats and the phenomenon of alliances or coalitions. The first of these lessons is that the current dispute over the allocation of PR seats, in particular, signals the need to assess the dichotomy built into the country's electoral system. The second is that, in their present form, the alliances impede the realisation of the broad aim of the MMP, namely, to ensure that Parliament includes minorities. And, finally, Lesotho must evolve a new and clear normative framework to accommodate this political phenomenon if only to avoid the anxiety and tension attendant on it.

\section{CONCLUSION}

Coalitions have historically been formed in Lesotho to fight political and other battles, or to promote and defend the shared interests of the groups forming them. After all, state formation in Lesotho in the 19th century rested primary on alliances forged both to achieve security for adjoining chiefdoms and to subdue a common enemy.

The type of party alliances created during the process leading to the February 2007 election, however, are novel both in character and scale and in the way in which they were formed. Yet they do not violate the electoral law as it is, though they detract from the MMP. Nor do they seem to threaten the democratisation process in Lesotho. But, to the extent that they are, in effect, voting blocs, they clearly defeat the MMP's purpose of accommodating small political parties, which now have to compete against them. They also enabled the two main political parties to reallocate to themselves the PR votes supposedly cast in favour of their small partners.

Therefore, tinged as they are with fraud, and manipulative in their thrust and consequences, these alliances signal the need to reconsider the existing electoral system, particularly to reassess the MMP's normative and legal frameworks to determine the nature of the changes necessary to ensure that party alliances are used to enhance and underpin democracy rather than to undermine and wreck it, or to avoid manipulation and misuse of the electoral system by unscrupulous elements of the elite. It is imperative that the entire nation be involved through its authentic representatives in any exercise leading to these reforms.

Any changes in the existing legal/ normative framework for elections must, however, aim not only to accommodate this apparently novel political dynamic but also to strip it of its palpably fraudulent and manipulative aspects, which 
conceal rather than reveal the actual performance of the individual parties and their popularity and strength.

In sum, we contend that political party alliances or coalitions, if these are to become established in Lesotho's politics, must enable the free and full exercise of choice by voters rather than simply re-allocating their votes to smaller partners and back as PR parliamentary seats to the big partners.

\section{- REFERENCES —}

Ball, A. 1993. Modern Politics and Government. Houndmills and London: Macmillan. Berridge, G R. 1992. International Politics, States, Power and Conflict since 1945. Hemel Hempstead: Harvester and Wheatsheaf.

Haque, R, M Harrop \& S Breslin. 1993. Comparative Politics. Houndmills and London: Macmillan.

Holsti K J. 1983. International Politics: A Framework for Analysis. Engle Cliffs: PrenticeHall International.

Kadima D. 2006. 'The Study of Party Coalitions in Africa: Importance, Scope Theory and Research Methodology'. In D Kadima (ed). The Politics of Party Coalitions in Africa. Auckland Park, Houghton: EISA/Konrad-Adenauer-Stiftung.

— \& R Kasenally. 2006. 'The Formation, Collapse and Revival of Political Party Coalitions in Mauritius: Ethnic Logic and Calculation at Play'. In D Kadima (ed). The Politics of Party Coalitions in Africa. Auckland Park, Houghton: EISA/ Konrad-Adenauer-Stiftung.

\& S Lembani. 2006. 'Making, Unmaking and Remaking Political Party Coalitions in Malawi: Explaining the Prevalence of Office-Seeking Behaviour'. In D Kadima (ed). The Politics of Party Coalitions in Africa. Auckland Park, Houghton: EISA/Konrad-Adenauer-Stiftung.

— \& F Owuor. 2006. 'The National Rainbow Coalition: Achievements and Challenges of Building and Sustaining a Broad-Based Political Party Coalition'. In D Kadima (ed). The Politics of Party Coalitions in Africa. Auckland Park, Houghton: EISA/Konrad-Adenauer-Stiftung.

Levine, H M. 1993. Political Issues Debated: An Introduction to Politics. Englewood Cliffs: Prentice Hall.

Macaefa, B, MP and Leader of LWP. 2007. Telephone interview, 12 September.

Makoa, F K. 2000. 'The Notion of Inclusive Democracy: What is New, and Has Lesotho With its Reformed Electoral System Edged Any Closer to This Ideal?' Lesotho Law Journal 13(1\& 2).

. 2005. 'Conflict Resolution and Peace Building Through Electoral and Parliamentary Reforms: A Note on Lesotho's Mixed-Member Parliament (MMP)'. Lesotho Law Journal 15(1). 
Motikoe, D, MP and NIP Deputy Leader. 2007. Telephone interview, 12 September. Motsamai, N, Speaker, Lesotho National Assembly. 2007. Remarks on the Occasion of the Opening of the Second Meeting of the First Session of the Seventh Parliament of the Kingdom of Lesotho, 7 September.

Nyaka, L. 2007. 'Opposition join hands in battle for Makaling'. Public Eye 11(35), 31 August.

Nyeko, B. 2002. 'The Independence Movement, 1952-1966'. In N W Pule \& M Thabane (eds). Essays on Aspects of the Political Economy of Lesotho. Roma: National University of Lesotho.

Oyugi, W O. 2006. 'Coalition Politics and Coalition Governments in Africa'. Journal of Contemporary African Studies 24(1), January.

Raditapole, K, MP, ACP. 2007. Telephone interview, 12 September.

Roskin, M G, R L Cord, J A Medeiros \& W S Jones. 2000. Political Science: An Introduction. Upper Saddle River: Prentice Hall.

Strom, G W. 1978. Development and Dependence in Lesotho the Enclave of South Africa. Stockholm: LiberTryck.

Volden, C \& C J Carruba. 2004. 'The Formation of Oversized Coalitions in Parliamentary Democracies'. American Journal of Political Science 48(3), July. 